\title{
Microbial characterization of an artisanal production of Robiola di Roccaverano cheese
}

\author{
Federica Biolcati, ${ }^{1 *} \odot$ Christian Andrighetto, ${ }^{2} \odot$ Maria Teresa Bottero, ${ }^{1} \odot$ and Alessandra Dalmasso ${ }^{1} \odot$ \\ ${ }^{1}$ Dipartimento di Scienze Veterinarie, Università di Torino, 10095 Grugliasco (TO), Italy \\ ${ }^{2}$ Veneto Agricoltura, Istituto per la Qualità e le Tecnologie Agroalimentari, 36016 Thiene (VI), Italy
}

\begin{abstract}
Robiola di Roccaverano, from the Piedmont region of Italy, is a Protected Designation of Origin soft cheese made with raw goat milk. The peculiarity of this cheese is that during the manufacturing process, a natural starter culture (NC) is added to raw milk. This study examined the viable microorganisms of technological interest, including lactic acid bacteria and fungal populations, in samples of raw milk, NC, and fresh and ripened cheese collected from one dairy using culturedependent techniques. First, the isolated colonies were analyzed using random amplification of polymorphic DNA (RAPD) PCR, and strains with similar fingerprints were clustered together. Further, representative isolates of each group were subjected to $16 \mathrm{~S}$ or $26 \mathrm{~S}$ ribosomal DNA sequencing. Finally, species-specific PCR was conducted to distinguish the Lactococcus lactis ssp. lactis and Lc. lactis ssp. cremoris. Among the studied lactic acid bacteria, 13 RAPD profiles were obtained, corresponding to 9 different bacterial species or subspecies. Concerning mold and yeast isolates, 5 species were found that coincided with 5 RAPD types. Observing the strains isolated in the study, Lc. lactis was the most prevalent species in raw milk and NC samples, and Leuconostoc mesenteroides was the predominant species identified in 5- and 15-d cheese isolates. Furthermore, whereas only these 2 species were detected in NC, Enterococcus and Lactobacillus genera were found in raw milk and cheese, respectively. Concerning the mold and yeast isolates, in NC Kluyveromyces spp. was mainly found, and in cheese samples the representative species were Geotrichum candidum and Yarrowia lipolytica. Finally, raw milk and cheese safety were evaluated, and the samples complied with the standard required by European Commission regulation number 2073/2005.
\end{abstract}

Received August 14, 2019.

Accepted January 14, 2020.

*Corresponding author: federica.biolcati@unito.it
Key words: Robiola di Roccaverano, natural starter culture, lactic acid bacteria, fungal population

\section{INTRODUCTION}

Italy has an ancient tradition in the production of dairy products, with a wide variety of cheeses that are strongly related to their place of origin. Some of these products have received Protected Designation of Origin (PDO) status along with the strict production requirements that this designation entails. Among these, Robiola di Roccaverano cheese holds high social and economic interest in the Piedmont region (northwest Italy), and it is the only Italian goat milk cheese that has been awarded with a PDO. Robiola di Roccaverano is a soft and creamy cheese made with at least $50 \%$ raw goat milk, with the possible addition of cow or ewe milk. Technical procedures establish that natural starter culture (NC) obtained from a back-slopping process must be used during artisanal Robiola di Roccaverano production. In detail, fermented milk from a previous fermentation process is added at room temperature to fresh raw milk from 2 consecutive milking sessions (afternoon and morning). Curd, obtained with goat or cow rennet, is inverted into a circular mold to allow the whey to release. The Robiola di Roccaverano can be consumed as fresh cheese after $4 \mathrm{~d}$ or allowed to ripen for up to 15 d (Gazzetta Ufficiale della Repubblica Italiana, 2006).

In traditional cheeses, such as Robiola di Roccaverano, the organoleptic features and quality of the final product are strongly influenced by the microbial ecosystem of raw materials that are not thermally treated (Quigley et al., 2011; Montel et al., 2014). Moreover, the traditional manufacturing practices and the addition of $\mathrm{NC}$ obtained by a back-slopping process rather than commercial starter allow the development of a unique independent microbial community that is adapted to the artisanal dairy environment (Smid et al., 2014; Bassi et al., 2015).

The microorganisms mainly involved in dairy production are lactic acid bacteria (LAB), naturally pres- 
ent in raw milk, due to their ability to rapidly ferment lactose to lactate. Among this group, the most relevant to Robiola di Roccaverano are the Lactococcus, Leuconostoc, Streptococcus, and Enterococcus genera. In the first steps of cheese production, mesophilic starter LAB (SLAB), principally Lactococcus lactis and Leuconostoc spp., are found. During ripening, nonstarter LAB (NSLAB), mainly lactobacilli and pediococci, are present (Wouters et al., 2002). Together with LAB, molds and yeasts in dairy products also contribute to cheese ripening through lactose fermentation, proteolysis, lipolysis, lactate consumption, and aroma compound production (Quigley et al., 2013).

Traditionally, microbial species in fermented products were detected and identified using biochemical and phenotypic tests (Rossetti and Giraffa, 2005; Feligini et al., 2012). However, these methods alone are not optimal for studying microbial communities in complex matrices because they lack specificity and, in some cases, do not permit certain identification of species. In the last 2 decades, with the advent of molecularbased techniques, culture-dependent approaches to identifying microbial populations have been improved. The most useful techniques are based on DNA analysis, such as restriction fragment length polymorphism PCR, 16S ribosomal DNA (rDNA) sequencing, and random amplification of polymorphic DNA (RAPD)PCR, applied singularly or in combination. Random amplified polymorphic DNA PCR has been widely used to study the dairy environment, allowing interspecies and to some extent intraspecies differentiation (Rossetti and Giraffa, 2005; Gala et al., 2008; Randazzo et al., 2009; Quigley et al., 2011; Soto Del Rio et al., 2016). In contrast, culture-independent methods are the ultimate tools for studying the microbial community in dairy products. Among these, PCR denaturing gradient gel electrophoresis (DGGE), PCR temporal temperature gradient gel electrophoresis, and, more recently, high-throughput DNA sequencing are widely applied (Flórez and Mayo, 2006; Martín-Platero et al., 2009; Dalmasso et al., 2016). These techniques do not allow discrimination between live and dead microorganisms. Consequently, the combination of culture-dependent and culture-independent methods has been demonstrated to be the most reliable approach to studying food-associated microbiota (Temmerman et al., 2004).

Several studies investigating the microbial populations involved in the manufacturing processes of high-value commercial cheese products, such as Grana Padano, Mozzarella di Bufala, and Feta cheese, have been conducted (Ercolini et al., 2004; Santarelli et al., 2013; Bozoudi et al., 2016). In recent years, research interest has been directed toward niche products whose production has a historical and traditional relevance and is confined to a specific geographical region (Alessandria et al., 2010; Riquelme et al., 2015; Dalmasso et al., 2016).

The microbial population of Robiola di Roccaverano cheese has been investigated using classical microbiology and PCR-DGGE in studies focusing on cheese from different dairies (Bonetta et al., 2008a,b). The main objective of this study was to characterize the biodiversity of LAB, molds, and yeasts through the analysis of the viable microbiota involved in the production of Robiola di Roccaverano cheese. Culture-dependent techniques were applied to samples of raw milk, NC, and fresh and ripened cheese, and a safety assessment was conducted.

\section{MATERIALS AND METHODS}

\section{Strains Isolation Using Classical Microbiology}

The production of Robiola di Roccaverano from one artisanal cheese factory was analyzed. Samples of NC $(\mathrm{n}=12)$, raw goat milk $(\mathrm{n}=12), 5$-d ripened cheese $(\mathrm{n}=12)$, and $15-\mathrm{d}$ ripened cheese $(\mathrm{n}=12)$ from 12 independent batches were collected in different periods of the year. Within the same batch, samples were matched. Raw milk (before starter addition) and NC were collected on the first day of production, and the corresponding fresh and matured cheeses were sampled after 5 and 15 d, respectively. Samples were transported in sterile conditions and analyzed within 2 to $3 \mathrm{~h}$ of sampling.

Ten grams or $10 \mathrm{~mL}$ of each sample was first homogenized with a sterile physiological saline solution and peptone (85:15 vol/vol; $90 \mathrm{~mL}$; Oxoid Ltd., Basingstoke, UK) using a Stomacher 400 Circulator (Seward Ltd., Worthing, UK) at $230 \mathrm{rpm}$ for $1 \mathrm{~min}$. Subsequently, serial dilutions were prepared with the same saline solution.

Lactobacilli were isolated using De Man, Rogosa and Sharpe (MRS) agar (Oxoid Ltd.) at $31^{\circ} \mathrm{C}$ for $72 \mathrm{~h}$ in an anaerobic jar with an AnaeroGen $2.5 \mathrm{~L}$ (Oxoid Ltd.). Lactococci and streptococci were grown on M17 agar (Oxoid Ltd.) in aerobic conditions for $48 \mathrm{~h}$ at $31^{\circ} \mathrm{C}$. Molds and yeasts were grown on OGYE agar (Oxoid Ltd.) at $25^{\circ} \mathrm{C}$ for $5 \mathrm{~d}$.

For each sample, 5 LAB (2 from M17 and 3 from MRS culture media) and 3 mold and yeast colonies were randomly collected from each sample based on different morphology (shape and color). Approximatively $240 \mathrm{LAB}$ and 144 molds and yeasts were collected. The confirmation of the colonies was performed using Gram staining and catalase test to discard non-lactic colonies. Gram-positive and catalase-negative strains were then inoculated in brain heart infusion broth (Oxoid Ltd.) and yeast extract peptone dextrose broth (Sigma- 
Aldrich, St. Louis, MO). The growth conditions were as previously mentioned. Hereafter, isolates were stored in sterile glycerol $(15 \% \mathrm{vol} / \mathrm{vol})$ at $-80^{\circ} \mathrm{C}$ until further analysis.

\section{Safety Assessment}

To evaluate the safety of raw goat milk and cheese samples, the presence of Salmonella spp. and Listeria monocytogenes was monitored according to ISO standard 6579-1:2017 (ISO, 2017a) and ISO standard 11290-1:2017 (ISO, 2017b), respectively, reported in European Commission regulation number 2073/2005 (European Commission, 2005). Moreover, the number of coagulase-positive staphylococci was evaluated at $37^{\circ} \mathrm{C}$ for $48 \mathrm{~h}$ on Baird-Parker RPF agar (Oxoid Ltd.) following ISO standard 6888-1:1999 (ISO, 1999).

\section{Strain Identification Using Molecular Methods}

After the isolation step, viable LAB, mold, and yeast colonies were characterized using molecular techniques (RAPD-PCR, 16S rDNA sequencing, 26S rDNA sequencing, and species-specific PCR) as described below. Before use, the bacterial and fungal colonies were grown overnight and lysed by microLysis-Plus (Microzone Ltd., Brightone, UK), and $1 \mu \mathrm{L}$ of cell lysate was used for the following biomolecular analysis. Biodiversity of LAB was assessed using RAPD-PCR with D11344 primer (Andrighetto et al., 2002). The amplification conditions were as follow: initial step of $94^{\circ} \mathrm{C}$ for $2 \mathrm{~min}$; 35 cycles of $94^{\circ} \mathrm{C}$ for $1 \mathrm{~min}, 42^{\circ} \mathrm{C}$ for $1 \mathrm{~min}, 72^{\circ} \mathrm{C}$ for 1 min $30 \mathrm{~s}$; and a final step at $72^{\circ} \mathrm{C}$ for $10 \mathrm{~min}$. Fungal strain diversity was analyzed with M13 primer for 35 cycles of $94^{\circ} \mathrm{C}$ for $1 \mathrm{~min}, 45^{\circ} \mathrm{C}$ for $20 \mathrm{~s}$, ramp to $72^{\circ} \mathrm{C}$ at $0.5^{\circ} \mathrm{C} / \mathrm{s}$, and $72^{\circ} \mathrm{C}$ for $2 \mathrm{~min}$ (Suzzi et al., 2000).

The amplification products were separated by electrophoresis on $1.5 \%$ (wt/vol) gel using $0.5 \times$ Trisborate-EDTA buffer at $5 \mathrm{~V} / \mathrm{cm}$ for $3 \mathrm{~h}$. The gels were treated with a solution of gel red $1 \times$ (Biotium Inc., Fremont, CA) for $45 \mathrm{~min}$ and captured with Image
Master VDS (Pharmacia Biotech, Piscataway, NJ). The obtained profiles were grouped with Gel Compar II (Applied Maths, Sint-Martens-Latem, Belgium) for LAB and Gel Compar 4.0 for yeasts and molds using the Pearson product-moment correlation coefficient and unweighted pair group method with arithmetic mean cluster analysis. The fingerprint obtained was identified through comparison of each strain profile with a RAPD types database, present in Veneto Agricoltura laboratory (Thiene, PD, Italy).

Subsequently, representative isolates from the different RAPD-PCR clusters were subjected to DNA sequencing using a 3130 (4-capillary) genetic analyzer (Applied Biosystems, Foster City, CA). The V1-V3 region of the bacterial $16 \mathrm{~S}$ rDNA was amplified using primer pairs P1 (Klijn et al., 1991) and P2 (Muyzer et al., 1993), whereas the D1/D2 domain of $26 \mathrm{~S}$ rDNA of yeasts and molds was amplified following the protocol described by Kurtzman and Robnett (1998). The obtained sequences were aligned with the sequences available in public databases such as RDP Release 11 (https://rdp.cme.msu.edu/) and the National Center for Biotechnology Information (https://blast.ncbi .nlm.nih.gov/Blast.cgi). Finally, due to the important number of Lc. lactis detected among LAB, a PCR was conducted to distinguish the 2 subspecies, Lc. lactis ssp. lactis and Lc. lactis ssp. cremoris ( $\mathrm{Pu}$ et al., 2002). Primer sequences are reported in Table 1.

\section{RESULTS AND DISCUSSION}

In this study, we investigated the viable microbiota dynamics occurring throughout the production of Robiola di Roccaverano cheese at a single facility, following the main steps of production (NC, milk, 5-d ripened cheese, and 15-d ripened cheese). A culture-based approach was used to achieve the aims of the study.

The initial number of phenotypically detected isolates was reduced after the confirmation step. Finally, a total of $164 \mathrm{LAB}$ and 101 mold and yeast colonies were confirmed and further analyzed. The distribution of the

Table 1. Primers used to identify lactic acid bacteria, molds, and yeasts with molecular methods

\begin{tabular}{llll}
\hline Primer & Sequence $\left(5^{\prime}-3^{\prime}\right)$ & Molecular technique $^{1}$ & Reference \\
\hline M13 & GAGGGTGGCGGTTCT & RAPD-PCR & Andrighetto et al. (2002) \\
D11344 & AGTGAATTCGCGGTGAGATGCCA & RAPD-PCR & Suzzi et al. (2000) \\
P1 & GCGGCGTGCCTAATACATGC & 16S rDNA sequencing & Klijn et al. (1991) \\
P2 & ATTACCGCGGCTGCTGG & 16S rDNA sequencing & Muyzer et al. (1993) \\
NL1 & GCATATCAATAAGCGGAGGAAAAG & 26S rDNA sequencing & Kurtzman and Robnett (1998) \\
NL4 & GGTCCGTGTTTCAAGACGG & 26S rDNA sequencing & Kurtzman and Robnett (1998) \\
LacreR & GGGATCATCTTTGAGTGAT & Species-specific PCR & Pu et al. (2002) \\
LacF & GTACTTGTACCGACTGGAT & Species-specific PCR & Pu et al. (2002) \\
CreF & GTACTTGTACCGACTGGAT & Species-specific PCR & Pu et al. (2002) \\
\hline
\end{tabular}

${ }^{1} \mathrm{RAPD}=$ random amplified polymorphic DNA; rDNA $=$ ribosomal DNA. 
strains among the samples is reported in Supplemental Table S1 (https://doi.org/10.3168/jds.2019-17451).

\section{Safety Assessment}

The microbiological parameters of European Commission regulation number 2073/2005 (European Commission, 2005) were evaluated on raw milk and on 5- and 15-d ripened cheese. Safety parameters complied with the standard of law: Salmonella spp. and Lis. monocytogenes were absent in $25 \mathrm{~g}$ or $25 \mathrm{~mL}$ of product, and the total counts of coagulase-positive staphylococci were within the required limits (Supplemental Table S2; https://doi.org/10.3168/jds.2019-17451). These results agreed with a previous study that assessed the safety of Robiola di Roccaverano cheese (Bonetta et al., 2008a). It is worth noting that the absence of foodborne pathogens demonstrates that a high standard of hygiene can be met while maintaining the artisanal practices characteristic of the traditional cheese-making process. This is of particular importance considering that no thermal process is applied to the final product.

Alternatively, even if no analyses were performed to assess the role of LAB in the inhibition of pathogen growth, it could be supposed that the high number of LAB found in the analyzed samples (Supplemental Table S2; https://doi.org/10.3168/jds.2019-17451) was related to the absence of pathogenic bacteria. In fact, the ability of LAB isolates from artisanal cheese to inhibit the growth of undesirable bacteria has been assessed (Dal Bello et al., 2010; Ribeiro et al., 2016; Yoon et al., 2016). Lactic acid bacteria could exhibit an antagonistic role against pathogens through the production of antimicrobial substances such as bacteriocin, organic acid, and hydrogen peroxide. Consequently, the rapid acid production could lead to a reduction in $\mathrm{pH}$ and thus inhibit the growth of other species (Lindgren and Dobrogosz, 1990).

\section{LAB Diversity in the Production Chain}

Concerning the 164 LAB isolates, RAPD-PCR was able to distinguish 13 different clusters corresponding to 9 different bacterial species or subspecies (Figures 1 and 2). The number of strains isolated from each matrix and the species identified are reported in Table 2.

The most abundant isolated species was Lc. lactis (59\%), grouped in 9 clusters (Figure 1). Among these isolates, species-specific PCR (Pu et al., 2002) highlighted that $32 \%$ were Lc. lactis ssp. cremoris and $26 \%$ were Lc. lactis ssp. lactis (Figure 3). This finding could be expected due to the culturing conditions used for the isolation. In addition, because thermal treatments on raw material are not permitted during the manu- facturing process of Robiola di Roccaverano cheese, the growth of mesophilic flora may be promoted. The second most representative LAB found was Leuconostoc mesenteroides (29\%), grouped in 2 clusters (Figures 2 and 3). Less abundant species included Enterococcus faecalis (4\%) and Lactobacillus plantarum (4\%; Figure 3).

Lactococcus lactis, the most abundant LAB isolated in this study through the culture-dependent approach used, is commonly found as a predominant microorganism in goat cheese. The main roles of Lc. lactis during the cheese-making process are acidification of the milk through production of lactic acid as well as a contribution to organoleptic features and the microbial quality of the final product (Ross et al., 2000). The high prevalence of this species has been reported in raw milk cheeses obtained without addition of commercial starter, such as Nicastrese, and in 2 highly appreciated farmhouse cheeses from Sierra de Aracena in southwest Spain (Martín-Platero et al., 2009; Pino et al., 2018). Moreover, Lc. lactis species were already detected in cheeses coming from different Robiola di Roccaverano dairies using a culture-independent approach (Bonetta et al., 2008b).

As reported in Figure 3, the LAB community of milk was different compared with the other matrices. It was dominated by Lc. lactis, particularly by Lc. lactis ssp. lactis, although few isolates of Lc. lactis ssp. cremoris were also identified. Among the other identified LAB, the second most prevalent species was Ent. faecalis, and only 1 strain belonged to Enterococcus hirae. The presence of enterococci was already reported in raw goat milk (Colombo et al., 2010). Members of the Enterococcus genus are commonly found in the intestinal tracts of humans and, less frequently, in animals, soil, water, plants, vegetables, birds, and insects (Gelsomino et al., 2002). However, the genus Enterococcus was not found among the colonies isolated from NC and from 5- and 15-d ripened cheeses (Table 2).

Compared with milk, the microbial colonies isolated from the indigenous $\mathrm{NC}$ samples highlighted some differences in terms of the number of species and type of species or subspecies found. The depth of sampling within each sample was limited. Only 2 species were detected in the NC: Lc. lactis (92\%), where Lc. lactis ssp. cremoris was the predominant subspecies (more than $80 \%$ of Lc. lactis strains), and Leu. mesenteroides (8\%; Figure 3).

The microbial composition of NC used in the production of Robiola di Roccaverano has not been investigated previously; however, several studies have been conducted on undefined starter culture applied in the cheese-manufacturing process using the metagenomic approach (Erkus et al., 2013; Frantzen et al., 2018). For 


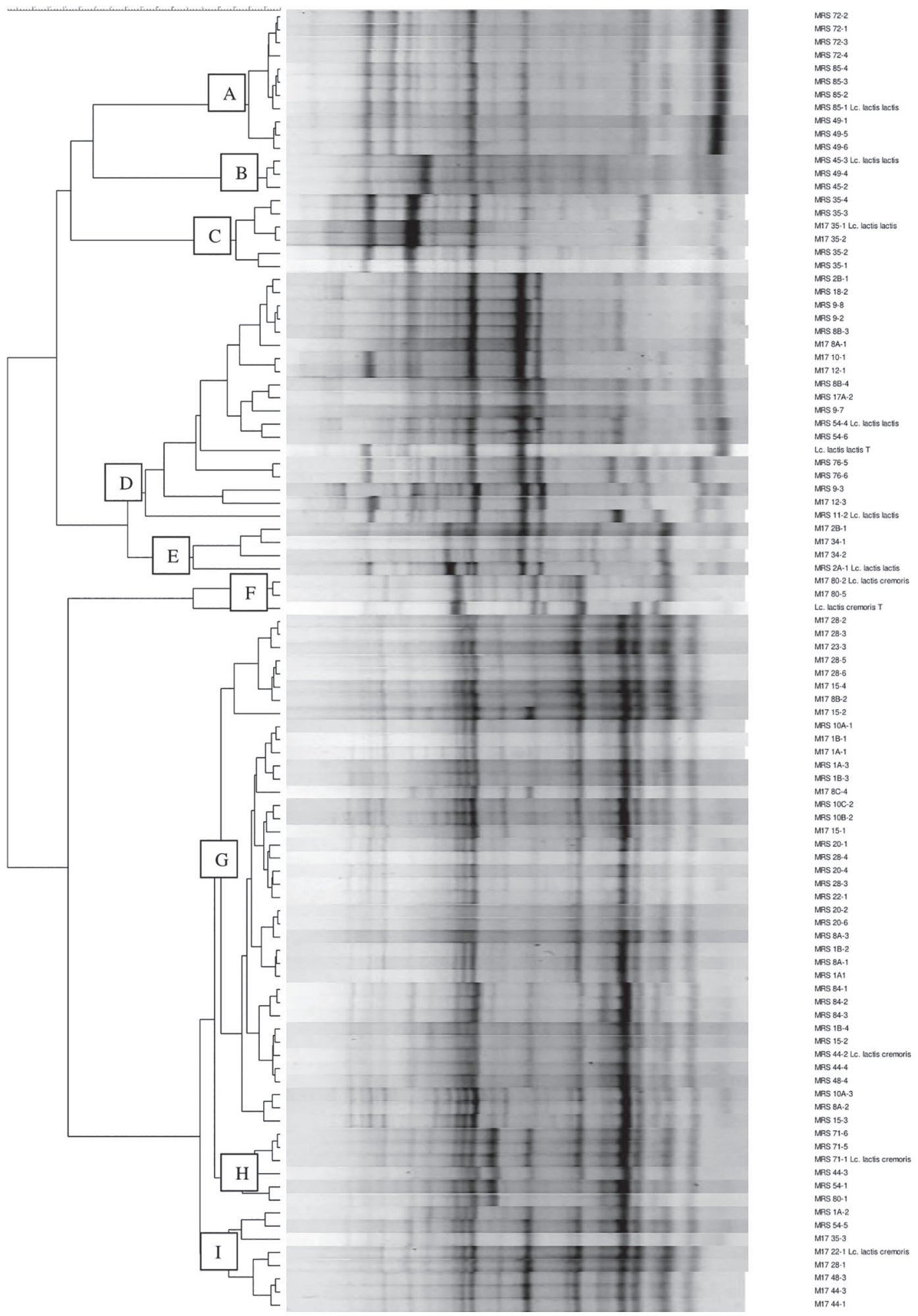

Figure 1. Random amplified polymorphic DNA PCR cluster of isolates belonging to the Lactococcus genus analyzed with the D11344 primer. 
example, the microbial community of undefined Gouda cheese starter was investigated, and the metagenome revealed that Lc. lactis was dominant in this starter culture, followed by a small community of Leu. mesenteroides (Erkus et al., 2013).
Despite the limited number of analyzed colonies, the composition of the viable microbial population of Robiola di Roccaverano cheese (both fresh and ripened) coming from the facility in this study seemed to be influenced by NC. In fact, mainly Leu. mesenteroides

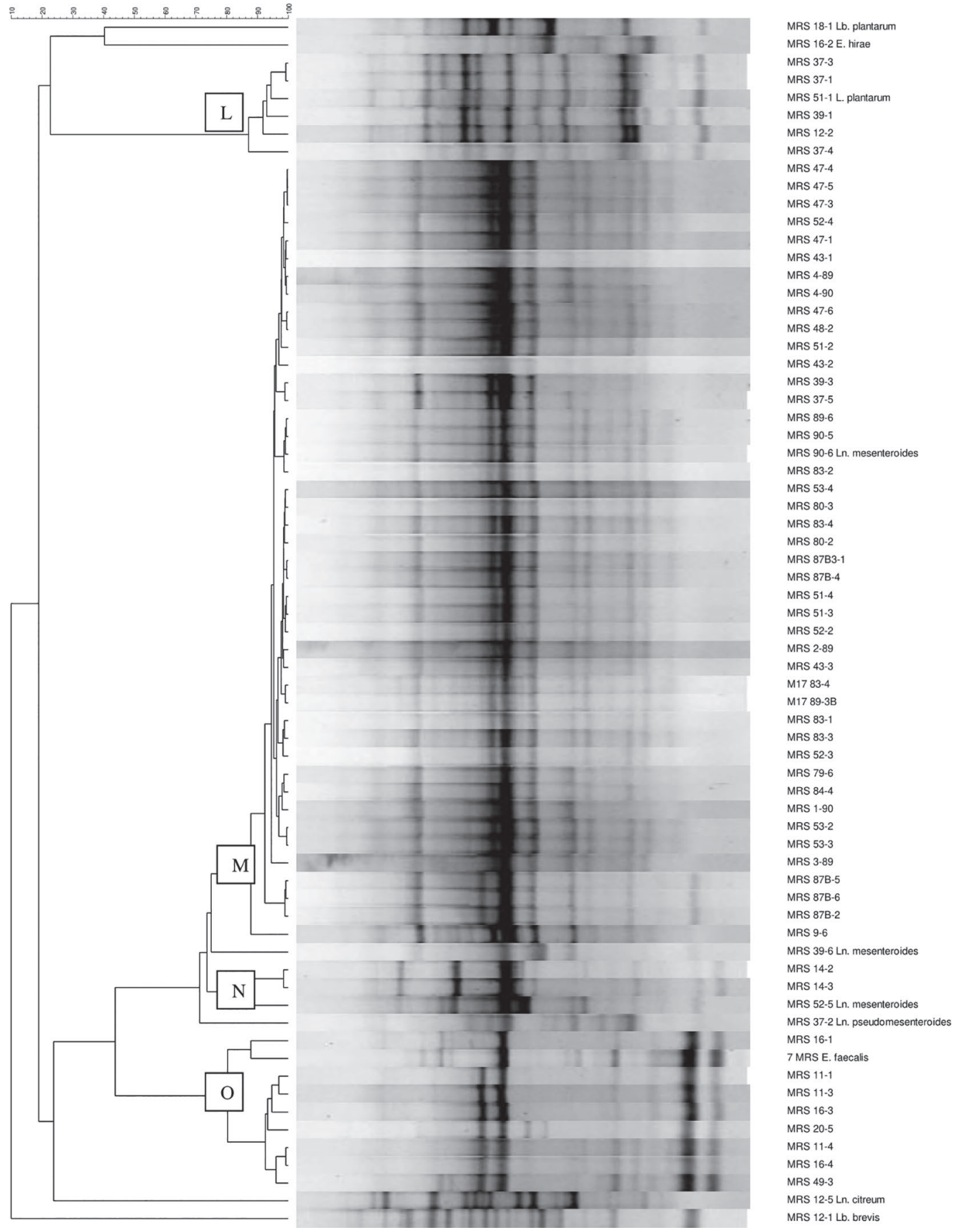

Figure 2. Random amplified polymorphic DNA PCR cluster of isolates belonging to non-Lactococcus genera analyzed with the D11344 primer. 
Table 2. Quantity and species of lactic acid bacteria (LAB) and fungal strains identified using random amplified polymorphic DNA PCR, 16S and 26S ribosomal DNA sequencing, and species-specific PCR

\begin{tabular}{lrrrr}
\hline Species identified & Milk & NC & 5-d cheese & 15-d cheese \\
\hline LAB population & & & & \\
Lactococcus lactis ssp. cremoris & 5 & 41 & 7 & 1 \\
Lactococcus lactis ssp. lactis & 24 & 5 & 9 & 5 \\
Leuconostoc mesenteroides & 0 & 4 & 22 & 0 \\
Enterococcus faecalis & 8 & 0 & 0 & 6 \\
Lactobacillus plantarum & 0 & 0 & 1 & 1 \\
Leuconostoc pseudomesenteroides & 0 & 0 & 0 & 0 \\
Lactobacillus brevis & 0 & 0 & 1 & 0 \\
Leuconostoc citreum & 0 & 0 & 1 & 35 \\
Enterococcus hirae & 1 & 0 & 0 & 22 \\
Total isolates & 38 & 50 & 41 & 1 \\
Fungal population & & & & 9 \\
Geotrichum candidum & 0 & 3 & 13 & 0 \\
Kluyveromyces marxianus & 0 & 1 & 5 & 0 \\
Saturnispora silvae & 0 & 0 & 8 & 0 \\
Yarrowia lipolytica & 0 & 0 & 15 & 0 \\
Kluyveromyces lactis & 0 & 8 & 2 & 41 \\
Candida pararugosa & 1 & 1 & 0 & 0 \\
Rhodotorula mucilaginosa & 1 & 0 & 0 & 0 \\
Meyerozyma guilliermondii & 0 & 1 & 0 & \\
Trichosporon coremiiforme & 0 & 0 & 1 & \\
Total isolates & 2 & 14 & 44 & \\
\hline
\end{tabular}

${ }^{1}$ Natural starter culture.

and Lc. lactis strains were isolated (Figure 3). However, Leu. mesenteroides, which was not detectable in milk samples and present in low numbers in NC, was found with major prevalence in Robiola di Roccaverano cheese isolates in both 5 - and 15-d ripened cheese (Figure 3). This observation was expected because, as described by several authors, Leu. mesenteroides has a double role of SLAB and NSLAB: it usually grows poorly in milk, but it is particularly involved in the cheese-ripening process because it produces aroma compounds (acetaldehydes, diacetyl, acetoin; McSweeney and Sousa, 2000; Settanni and Moschetti, 2010). In conclusion, the short time of ripening of Robiola di Roccaverano (maximum $15 \mathrm{~d}$ ) probably did not allow for the growth of other species: NSLAB numbers increased over time, whereas SLAB numbers decreased (Settanni and Moschetti, 2010).

Even if the culturing approach applied did not permit a quantitative analysis, it was possible to observe that the number of Lc. lactis isolates decreased from $\mathrm{NC}$ to cheese, whereas the number of Leu. mesenteroides isolates increased from $\mathrm{NC}$ to cheese. However, this finding could also be related to the condition adopted for strain isolation.

Lactobacillus plantarum was also isolated in fresh and ripened cheese (Figure 3). In fact, the presence of this species has been reported in many cheese varieties. Lactobacillus plantarum is an NSLAB and could be involved in the maturation step because it is able to utilize several types of metabolites, such as lactate, amino acids, ribose, and $N$-acetylamino sugars, as nu- trient sources (Pisano et al., 2006; Martín-Platero et al., 2009; Pino et al., 2018).

An in-depth analysis of RAPD-PCR output showed different biotypes of each species (Table 3 ). The 97 profiles identified as Lc. lactis were grouped for similarity, as reported before, in 9 different clusters (Figure 1). Analyzing the distribution of the different biotypes, 5 of these belonged to Lc. lactis ssp. lactis (A, B, C, D, E) and 4 belonged to Lc. lactis ssp. cremoris (F, G, $\mathrm{H}, \mathrm{I}$ ). A few biotypes were exclusive of some matrices; for example, $\mathrm{A}, \mathrm{B}$, and $\mathrm{C}$ biotypes were found only in milk, and $\mathrm{F}$ and $\mathrm{H}$ were reported only in NC. However, D and $\mathrm{G}$ biotypes were ubiquitous along the dairy production chain. Among all of the isolates, profile $G$ was the most common, representative of 37 isolates. From the strains analyzed in this study, it could be supposed that some biotypes present only in milk (A, $\mathrm{B}, \mathrm{C})$ were lost through the production chain. On the contrary, biotypes D, E, G, and I persisted during the steps of the manufacturing process, suggesting their adaptability to the dairy environment along the year of production sampled.

Leuconostoc mesenteroides, the second most abundant species found through the isolation process, showed a low level of diversity. In fact, as reported in Table 3, only 2 biotypes were distinguished ( $\mathrm{M}$ and $\mathrm{N}$ ), where the most representative was cluster M. Some authors conducted a study in which Leu. mesenteroides strains were efficiently genotyped and subspecies were discriminated by means of different RAPD-PCR 


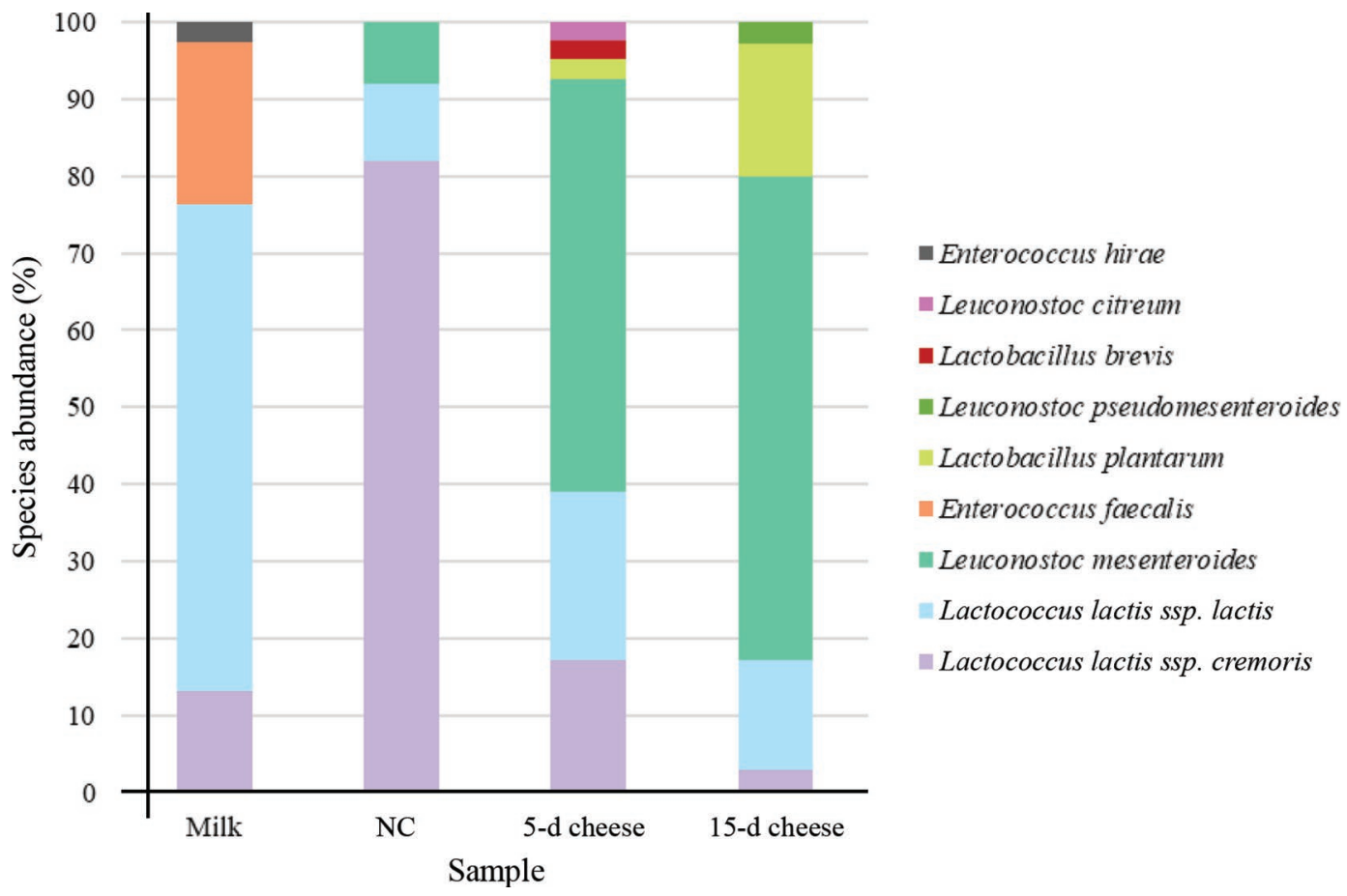

Figure 3. Abundance of lactic acid bacteria isolated along the production chain and identified using random amplified polymorphic DNA $\mathrm{PCR}, 16 \mathrm{~S}$ ribosomal DNA sequences, and species-specific PCR. $\mathrm{NC}=$ natural starter culture.

protocol (Perez et al., 2002). Thus, the limited number of Leu. mesenteroides biotypes reported in the present study could be due to a true lack of species diversity or to an inefficiency of the short arbitrary primer used to discriminate intraspecies differences of the isolates.

Generally, from the viable microbiota analyzed in this study, the variability in terms of biotypes showed that milk samples were the richest matrices, showing 7 different biotypes of Lc. lactis. On the contrary, cheese samples displayed poor diversity, with only 3 biotypes in fresh cheese and 2 in ripened cheese. In contrast, the $\mathrm{NC}$ showed medium diversity in terms of number of biotypes (5) found.

\section{Fungal Diversity in the Production Chain}

The biodiversity of the viable fungal population was analyzed using RAPD-PCR. The fingerprints obtained were grouped by similarity, and the representative isolates were sequenced. The number of strains isolated from each matrix and the species identified are reported in Table 2. The results showed 9 different RAPD types corresponding to an equal number of identified species (Figure 4). No information was obtained for the milk fungal population because of the limited number of molds and yeasts isolated (Supplemental Table S2; https://doi.org/10.3168/jds.2019-17451). This issue could be ascribed to a true lack of a fungal community in milk or to the low specificity of the culturing methods applied.

Considering the fungal population isolated, the yeast Geotrichum candidum was the most abundant species (37\%; Figure 5). Geotrichum candidum is commonly found in various habitats such as soil, grass, silage, plants, fruits, feed stuffs, insects, humans, other mammals, and dairy products. In fact, besides its natural

Table 3. Lactococcus lactis and Leuconostoc mesenteroides biotypes determined using random amplified polymorphic DNA PCR and number of isolates for each biotype ${ }^{1}$

\begin{tabular}{lllll}
\hline Species & Milk & NC & 5-d cheese & 15-d cheese \\
\hline Lactococcus lactis ssp. lactis & A11, B3, C6, D2, E2 & D3, E2 & D8, E1 & D5 \\
$\begin{array}{l}\text { Lactococcus lactis } \text { ssp. cremoris } \\
\text { Leuconostoc mesenteroides }\end{array}$ & G4, I1 & F2, G28, H6, I5 & G6, I1 N1 & M21, N1 \\
\hline
\end{tabular}

${ }^{1}$ Letters indicate biotypes A to N; numbers following letter = number of isolates for each biotype.

${ }^{2}$ Natural starter culture. 


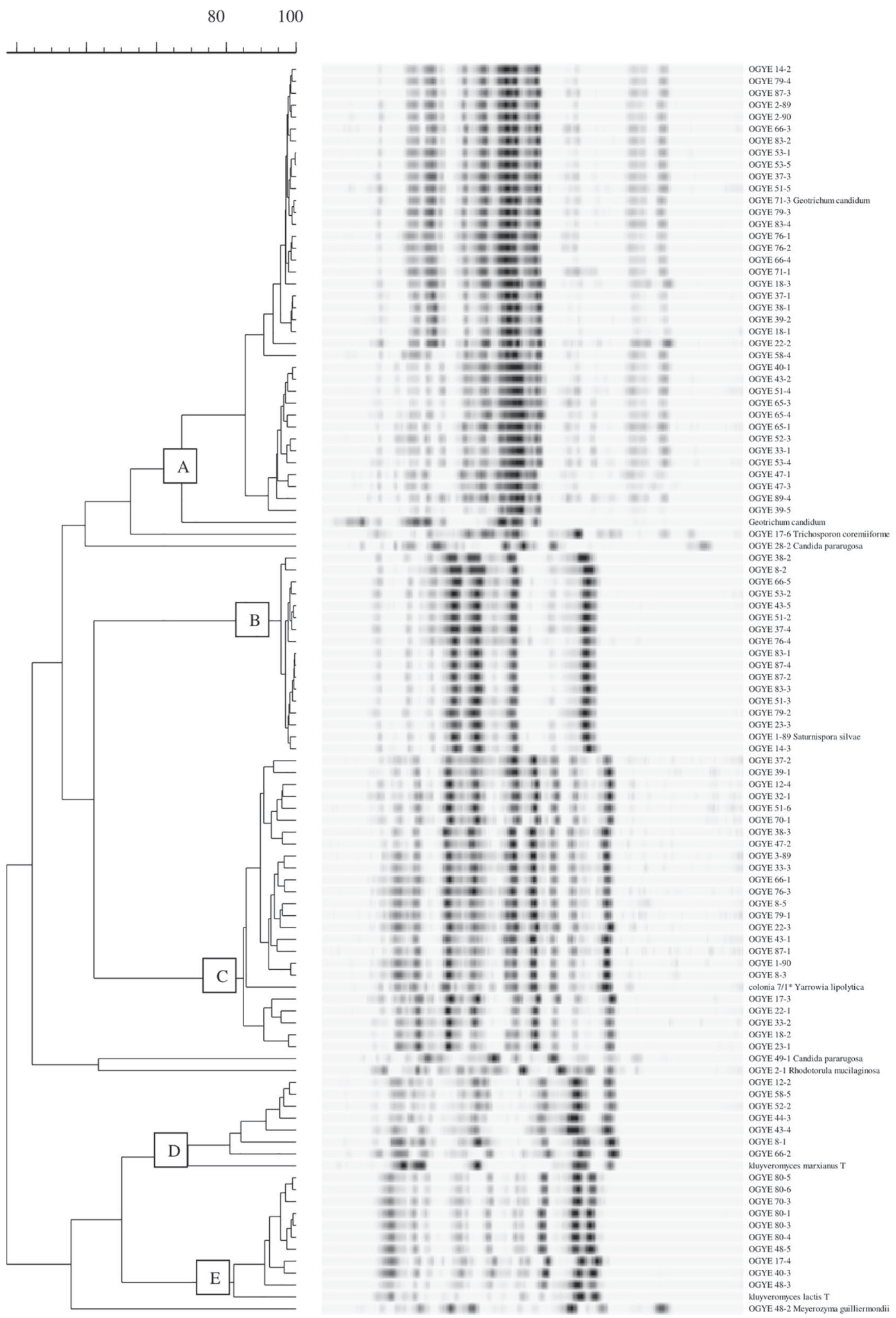

Figure 4. Random amplified polymorphic DNA PCR cluster of mold and yeast isolates analyzed with the M13 primer. 
presence in low numbers in milk, it is an important component of soft cheese made with different types of raw milk. Geotrichum candidum can produce several enzymes involved in the breakdown of protein and fat; therefore, it is responsible for the production of important aroma compounds. Due to these properties, it is sold as a selected starter to be used in cheese ripening (Boutrou and Guéguen, 2005). Moreover, the presence of Geotrichum spp. in Robiola di Roccaverano cheese through the DGGE approach has been previously reported (Bonetta et al., 2008b).

The second most prevalent identified species was Yarrowia lipolytica, a ubiquitous yeast that naturally grows on cheese surfaces. Due to its strong proteolytic and lipolytic capacities, it usually plays a role in cheese aroma formation and in texture development (Suzzi et al., 2001). Yarrowia lipolytica is one of the most common species occurring in blue cheese (Gkatzionis et al., 2013), but it was also found in Tomme d'Orchies and Livarot in studies conducted using a high-throughput DNA sequencing approach (Mounier et al., 2009; Ceugniez et al., 2015). Last, among the 101 isolates, the third most abundant yeast identified was Saturnispora sylvae, which has previously been reported in Roccaverano cheese (Bonetta et al., 2008b).

In the $\mathrm{NC}$ and cheese samples, a few colonies of Kluyveromyces lactis and Kluyveromyces marxianus were also identified among the isolates (Figure 5). These results were expected because $K$. marxianus could be a component of whey and milk starter; in fact, this organism is able to utilize lactose as a source of carbon (Binetti et al., 2013). Furthermore, Kluyveromyces spp. commonly has been found in dairy products, and recently its probiotic potential was assessed in isolates from Fiore Sardo cheese (Fadda et al., 2004). No different biotypes were found for each fungal isolate identified at the species level because RAPD-PCR with primer M13 did not allow the detection of strain biodiversity.

\section{CONCLUSIONS}

Regardless of the limitations of the culture-dependent methods, this study provides insight into the diversity of the viable $\mathrm{LAB}$ and fungal population present in the production of Robiola di Roccaverano. Many of the isolated microorganisms belonged to species that are known to be involved in the dairy process for their technological potential. Further studies could be necessary to better describe the entire microbiota involved in the manufacturing process of Robiola di Roccaverano cheese. In addition, comparison with other Robiola di Roccaverano facilities could be performed to assess whether the technical policies used determine some common characteristics among dairies.

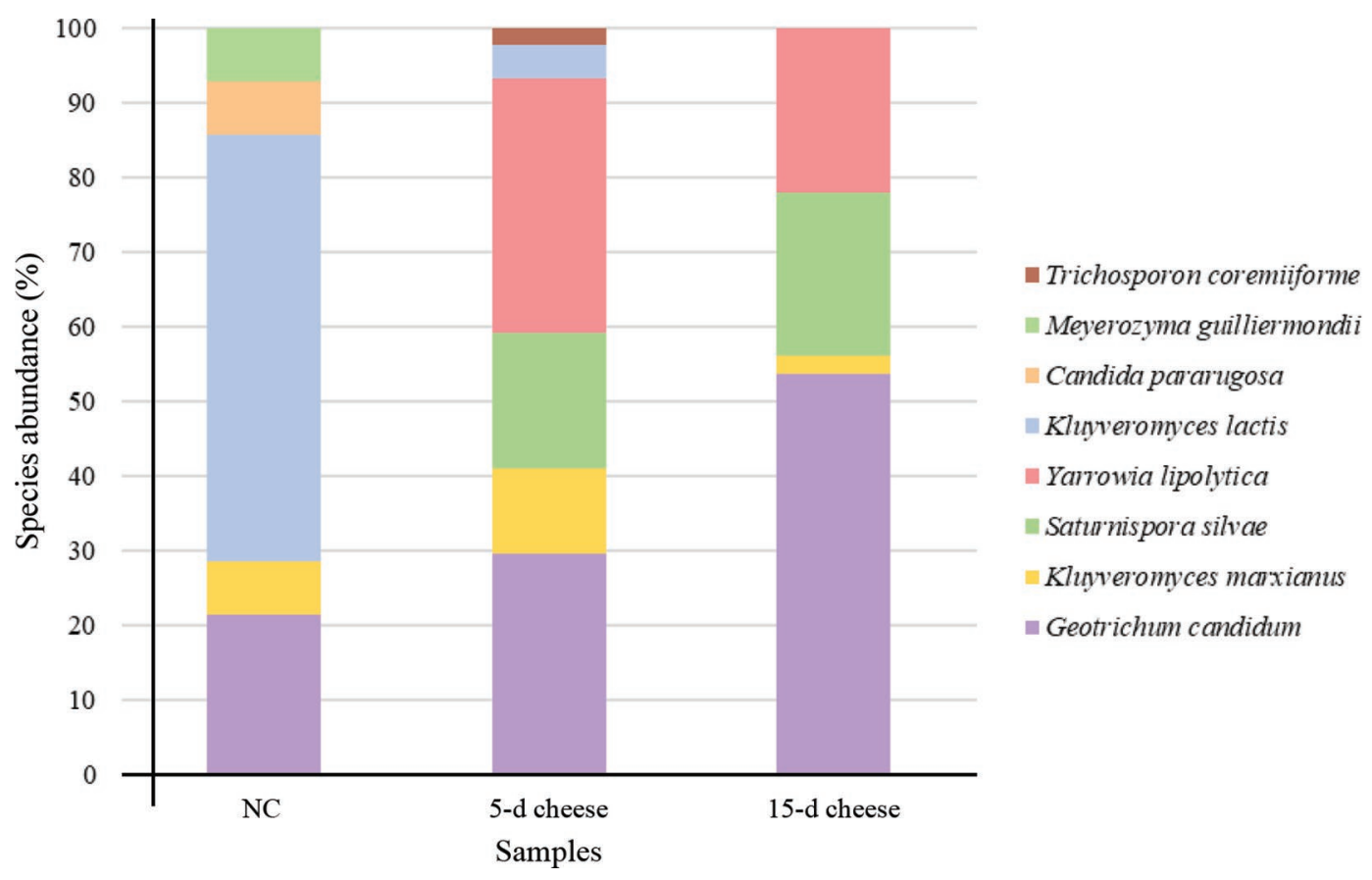

Figure 5. Abundance of fungal population isolated along the production chain and identified using random amplified polymorphic DNA PCR and $26 \mathrm{~S}$ ribosomal DNA sequences. $\mathrm{NC}=$ natural starter culture. 


\section{ACKNOWLEDGMENTS}

This work was supported by the University of Turin (Italy; 60\% grant). All authors participated in both research and manuscript preparation and have approved the final version of this article. The authors thank Rebecca Slavin (Teagasc, Moorepark, Ireland) for proofreading. The authors have stated no conflicts of interest.

\section{REFERENCES}

Alessandria, V., P. Dolci, K. Rantsiou, D. Pattono, A. Dalmasso, T. Civera, and L. Cocolin. 2010. Microbiota of the Planalto de Bolona: An artisanal cheese produced in uncommon environmental conditions in the Cape Verde Islands. World J. Microbiol. Biotechnol. 26:2211-2221. https://doi.org/10.1007/s11274-010-0406-7.

Andrighetto, C., F. Borney, A. Barmaz, B. Stefanon, and A. Lombardi. 2002. Genetic diversity of Streptococcus thermophilus strains isolated from Italian traditional cheeses. Int. Dairy J. 12:141-144. https://doi.org/10.1016/S0958-6946(01)00134-0.

Bassi, D., E. Puglisi, and P. S. Cocconcelli. 2015. Comparing natural and selected starter cultures in meat and cheese fermentations. Curr. Opin. Food Sci. 2:118-122. https://doi.org/10.1016/j.cofs 2015.03.002.

Binetti, A., M. Carrasco, J. Reinheimer, and V. Suárez. 2013. Yeasts from autochthonal cheese starters: Technological and functional properties. J. Appl. Microbiol. 115:434-444. https://doi.org/10 $.1111 /$ jam.12228.

Bonetta, S., S. Bonetta, E. Carraro, K. Rantsiou, and L. Cocolin. 2008a. Microbiological characterisation of Robiola di Roccaverano cheese using PCR-DGGE. Food Microbiol. 25:786-792. https://doi .org/10.1016/j.fm.2008.04.013.

Bonetta, S., J. D. Coïsson, D. Barile, S. Bonetta, F. Travaglia, G. Piana, E. Carraro, and M. Arlorio. 2008b. Microbiological and chemical characterization of a typical Italian cheese: Robiola di Roccaverano. J. Agric. Food Chem. 56:7223-7230. https://doi .org/10.1021/jf8000586.

Boutrou, R., and M. Guéguen. 2005. Interests in Geotrichum candidum for cheese technology. Int. J. Food Microbiol. 102:1-20. https://doi .org/10.1016/j.ijfoodmicro.2004.12.028

Bozoudi, D., S. Torriani, A. Zdragas, and E. Litopoulou-Tzanetaki. 2016. Assessment of microbial diversity of the dominant microbiota in fresh and mature PDO Feta cheese made at three mountainous areas of Greece. Lebensm. Wiss. Technol. 72:525-533. https:/ /doi.org/10.1016/j.lwt.2016.04.039.

Ceugniez, A., D. Drider, P. Jacques, and F. Coucheney. 2015. Yeast diversity in a traditional French cheese "Tomme d'orchies" reveals infrequent and frequent species with associated benefits. Food Microbiol. 52:177-184. https://doi.org/10.1016/j.fm.2015.08.001.

Colombo, E., L. Franzetti, M. Frusca, and M. Scarpellini. 2010. Phenotypic and genotypic characterization of lactic acid bacteria isolated from artisanal Italian goat cheese. J. Food Prot. 73:657-662. https: //doi.org/10.4315/0362-028X-73.4.657.

Dal Bello, B., K. Rantsiou, A. Bellio, G. Zeppa, R. Ambrosoli, T. Civera, and L. Cocolin. 2010. Microbial ecology of artisanal products from North West of Italy and antimicrobial activity of the autochthonous populations. Lebensm. Wiss. Technol. 43:1151-1159. https://doi.org/10.1016/j.lwt.2010.03.008.

Dalmasso, A., M. Soto del Rio, T. Civera, D. Pattono, B. Cardazzo, and M. T. Bottero. 2016. Characterization of microbiota in Plaisentif cheese by high-throughput sequencing. Lebensm. Wiss. Technol. 69:490-496. https://doi.org/10.1016/j.lwt.2016.02.004.

Ercolini, D., G. Mauriello, G. Blaiotta, G. Moschetti, and S. Coppola. 2004. PCR-DGGE fingerprints of microbial succession during a manufacture of traditional water buffalo mozzarella cheese. J.
Appl. Microbiol. 96:263-270. https://doi.org/10.1046/j.1365-2672 2003.02146.x

Erkus, O., V. C. L. de Jager, M. Spus, I. J. van Alen-Boerrigter, I. M. H. van Rijswijck, L. Hazelwood, P. W. M. Janssen, S. A. F. T. van Hijum, M. Kleerebezem, and E. J. Smid. 2013. Multifactorial diversity sustains microbial community stability. ISME J. 7:2126-2136. https://doi.org/10.1038/ismej.2013.108.

European Commission. 2005. Commission regulation (EC) no. 2073/2005 of 15 November 2005 on microbial criteria for foodstuffs. Off. J. L338:1-26.

Fadda, M. E., V. Mossa, M. B. Pisano, M. Deplano, and S. Cosentino. 2004. Occurrence and characterization of yeasts isolated from artisanal Fiore Sardo cheese. Int. J. Food Microbiol. 95:51-59. https:/ /doi.org/10.1016/j.ijfoodmicro.2004.02.001.

Feligini, M., S. Panelli, J. N. Buffoni, C. Bonacina, C. Andrighetto, and A. Lombardi. 2012. Identification of microbiota present on the surface of Taleggio cheese using PCR-DGGE and RAPD-PCR. J. Food Sci. 77:M609-M615. https://doi.org/10.1111/j.1750-3841 2012.02932.x.

Flórez, A. B., and B. Mayo. 2006. Microbial diversity and succession during the manufacture and ripening of traditional, Spanish, blue-veined Cabrales cheese, as determined by PCR-DGGE. Int. J. Food Microbiol. 110:165-171. https://doi.org/10.1016/j .ijfoodmicro.2006.04.016.

Frantzen, C. A., H. P. Kleppen, and H. Holo. 2018. Lactococcus lactis diversity in undefined mixed dairy starter cultures as revealed by comparative genome analyses and targeted amplicon sequencing of epsD. Appl. Environ. Microbiol. 84:e02199-17. https://doi.org/10 .1128/AEM.02199-17.

Gala, E., S. Landi, L. Solieri, M. Nocetti, A. Pulvirenti, and P. Giudici. 2008. Diversity of lactic acid bacteria population in ripened Parmigiano Reggiano cheese. Int. J. Food Microbiol. 125:347-351. https://doi.org/10.1016/j.ijfoodmicro.2008.04.008.

Gazzetta Ufficiale della Repubblica Italiana. 2006. Anno 147, No. 27, $55-56$.

Gelsomino, R., M. Vancanneyt, T. M. Cogan, S. Condon, and J. Swings. 2002. Source of enterococci in a farmhouse raw-milk cheese. Appl. Environ. Microbiol. 68:3560-3565. https://doi.org/ 10.1128/AEM.68.7.3560.

Gkatzionis, K., L. Hewson, T. Hollowood, J. Hort, C. E. R. Dodd, and R. S. T. Linforth. 2013. Effect of Yarrowia lipolytica on blue cheese odour development: Flash profile sensory evaluation of microbiological models and cheeses. Int. Dairy J. 30:8-13. https://doi.org/ 10.1016/j.idairyj.2012.11.010.

ISO. 2017a. ISO 6579-1:2017. Microbiology of the food chain-Horizontal method for the detection, enumeration and serotyping of Salmonella-Part 1: Detection of Salmonella spp. International Organization for Standardization, Geneva, Switzerland.

ISO. 2017b. ISO 11290-1:2017. Microbiology of the food chain-Horizontal method for the detection and enumeration of Listeria monocytogenes and of Listeria spp.-Part 1: Detection method. International Organization for Standardization, Geneva, Switzerland.

ISO. 1999. ISO 6888-1:1999. Microbiology of food and animal feeding stuffs - Horizontal method for the enumeration of coagulase-positive staphylococci (Staphylococcus aureus and other species) - Part 1: Technique using Baird-Parker agar medium. International Organization for Standardization, Geneva, Switzerland.

Klijn, N., A. H. Weerkamp, and W. M. De Vos. 1991. Identification of mesophilic lactic acid bacteria by using polymerase chain reactionamplified variable regions of $16 \mathrm{~S}$ rRNA and specific DNA probes. Appl. Environ. Microbiol. 57:3390-3393. https://doi.org/10.1128/ AEM.57.11.3390-3393.1991.

Kurtzman, C. P., and C. J. Robnett. 1998. Identification and phylogeny of ascomycetous yeasts from analysis of nuclear large subunit (26S) ribosomal DNA partial sequences. Antonie van Leeuwenhoek 73:331-371. https://doi.org/10.1023/a:1001761008817.

Lindgren, S. E., and W. J. Dobrogosz. 1990. Antagonistic activities of lactic acid bacteria in food and feed fermentations. FEMS Microbiol. Lett. 87:149-164. https://doi.org/10.1111/j.1574-6968.1990 .tb04885.x. 
Martín-Platero, A. M., M. Maqueda, E. Valdivia, J. Purswani, and M. Martínez-Bueno. 2009. Polyphasic study of microbial communities of two Spanish farmhouse goats' milk cheeses from Sierra de Aracena. Food Microbiol. 26:294-304. https://doi.org/10.1016/j fm.2008.12.004

McSweeney, P. L. H., and M. J. Sousa. 2000. Biochemical pathways for the production of flavour compounds in cheeses during ripening: A review. Lait 80:293-324. https://doi.org/10.1051/lait:2000127.

Montel, M.-C., S. Buchin, A. Mallet, C. Delbes-Paus, D. A. Vuitton, N. Desmasures, and F. Berthier. 2014. Traditional cheeses: Rich and diverse microbiota with associated benefits. Int. J. Food Microbiol. 177:136-154. https://doi.org/10.1016/j.ijfoodmicro.2014 .02 .019 .

Mounier, J., C. Monnet, N. Jacques, A. Antoinette, and F. Irlinger. 2009. Assessment of the microbial diversity at the surface of Livarot cheese using culture-dependent and independent approaches. Int. J. Food Microbiol. 133:31-37. https://doi.org/10.1016/j .ijfoodmicro.2009.04.020.

Muyzer, G., E. C. de Waal, and A. G. Uitterlinden. 1993. Profiling of complex microbial populations by denaturing gradient gel electrophoresis analysis of polymerase chain reaction-amplified genes coding for 16S rRNA. Appl. Environ. Microbiol. 59:695-700. https: //doi.org/10.1128/AEM.59.3.695-700.1993.

Perez, G., E. Cardell, and V. Zarate. 2002. Random amplified polymorphic DNA analysis for differentiation of Leuconostoc mesenteroides subspecies isolated from Tenerife cheese. Lett. Appl. Microbiol. 34:82-85. https://doi.org/10.1046/j.1472-765x.2002.01050.x.

Pino, A., L. Liotta, C. L. Randazzo, A. Todaro, A. Mazzaglia, F. De Nardo, V. Chiofalo, and C. Caggia. 2018. Polyphasic approach to study physico-chemical, microbiological and sensorial characteristics of artisanal Nicastrese goat's cheese. Food Microbiol. 70:143154. https://doi.org/10.1016/j.fm.2017.09.005.

Pisano, M. B., M. E. Fadda, M. Deplano, A. Corda, and S. Cosentino. 2006. Microbiological and chemical characterization of Fiore Sardo, a traditional Sardinian cheese made from ewe's milk. Int. J. Dairy Technol. 59:171-179. https://doi.org/10.1111/j.1471-0307 2006.00260.x.

Pu, Z. Y., M. Dobos, G. K. Y. Limsowtin, and I. B. Powell. 2002. Integrated polymerase chain reaction-based procedures for the detection and identification of species and subspecies of the Gram-positive bacterial genus Lactococcus. J. Appl. Microbiol. 93:353-361. https://doi.org/10.1046/j.1365-2672.2002.01688.x.

Quigley, L., O. O'Sullivan, T. P. Beresford, R. P. Ross, G. F. Fitzgerald, and P. D. Cotter. 2011. Molecular approaches to analysing the microbial composition of raw milk and raw milk cheese. Int. J. Food Microbiol. 150:81-94. https://doi.org/10.1016/j.ijfoodmicro 2011.08.001.

Quigley, L., O. O'Sullivan, C. Stanton, T. P. Beresford, R. P. Ross, G. F. Fitzgerald, and P. D. Cotter. 2013. The complex microbiota of raw milk. FEMS Microbiol. Rev. 37:664-698. https://doi.org/10 .1111/1574-6976.12030.

Randazzo, C. L., C. Caggia, and E. Neviani. 2009. Application of molecular approaches to study lactic acid bacteria in artisanal cheeses. J. Microbiol. Methods 78:1-9. https://doi.org/10.1016/j mimet.2009.04.001

Ribeiro, S. C., P. M. O'Connor, R. P. Ross, C. Stanton, and C. C. G. Silva. 2016. An anti-listerial Lactococcus lactis strain isolated from
Azorean Pico cheese produces lacticin 481. Int. Dairy J. 63:18-28. https://doi.org/10.1016/j.idairyj.2016.07.017.

Riquelme, C., S. Câmara, M. L. Dapkevicius, P. Vinuesa, C. C. G. da Silva, F. X. Malcata, and O. A. Rego. 2015. Characterization of the bacterial biodiversity in Pico cheese (an artisanal Azorean food). Int. J. Food Microbiol. 192:86-94. https://doi.org/10.1016/ j.ijfoodmicro.2014.09.031.

Ross, R. P., C. Stanton, C. Hill, G. F. Fitzgerald, and A. Coffey. 2000. Novel cultures for cheese improvement. Trends Food Sci. Technol. 11:96-104. https://doi.org/10.1016/S0924-2244(00)00057-1.

Rossetti, L., and G. Giraffa. 2005. Rapid identification of dairy lactic acid bacteria by M13-generated, RAPD-PCR fingerprint databases. J. Microbiol. Methods 63:135-144. https://doi.org/10.1016/j .mimet.2005.03.001.

Santarelli, M., B. Bottari, C. Lazzi, E. Neviani, and M. Gatti. 2013. Survey on the community and dynamics of lactic acid bacteria in Grana Padano cheese. Syst. Appl. Microbiol. 36:593-600. https:// doi.org/10.1016/j.syapm.2013.04.007.

Settanni, L., and G. Moschetti. 2010. Non-starter lactic acid bacteria used to improve cheese quality and provide health benefits. Food Microbiol. 27:691-697. https://doi.org/10.1016/j.fm.2010.05.023.

Smid, E. J., O. Erkus, M. Spus, J. C. Wolkers-Rooijackers, S. Alexeeva, and M. Kleerebezem. 2014. Functional implications of the microbial community structure of undefined mesophilic starter cultures. Microb. Cell Fact. 13(Suppl. 1):S2. https://doi.org/10.1186/ 1475-2859-13-S1-S2.

Soto Del Rio, M., C. Andrighetto, A. Dalmasso, A. Lombardi, T. Civera, and M. T. Bottero. 2016. Isolation and characterisation of lactic acid bacteria from donkey milk. J. Dairy Res. 83:383-386. https://doi.org/10.1017/S0022029916000376.

Suzzi, G., M. T. Lanorte, F. Galgano, C. Andrighetto, A. Lombardi, R. Lanciotti, and M. E. Guerzoni. 2001. Proteolytic, lipolytic and molecular characterisation of Yarrowia lipolytica isolated from cheese. Int. J. Food Microbiol. 69:69-77. https://doi.org/10.1016/ s0168-1605(01)00574-8.

Suzzi, G., A. Lombardi, M. T. Lanorte, M. Caruso, C. Andrighetto, and F. Gardini. 2000. Phenotypic and genotypic diversity of yeasts isolated from water-buffalo Mozzarella cheese. J. Appl. Microbiol. 88:117-123. https://doi.org/10.1046/j.1365-2672.2000.00926.x.

Temmerman, R., G. Huys, and J. Swings. 2004. Identification of lactic acid bacteria: Culture-dependent and culture-independent methods. Trends Food Sci. Technol. 15:348-359. https://doi.org/10 .1016/j.tifs.2003.12.007.

Wouters, J. T. M., E. H. E. Ayad, J. Hugenholtz, and G. Smit. 2002. Microbes from raw milk for fermented dairy products. Int. Dairy J. 12:91-109. https://doi.org/10.1016/S0958-6946(01)00151-0.

Yoon, Y., S. Lee, and K.-H. Choi. 2016. Microbial benefits and risks of raw milk cheese. Food Control 63:201-215. https://doi.org/10 .1016/j.foodcont.2015.11.013.

\section{ORCIDS}

Federica Biolcati ๑ https://orcid.org/0000-0002-0797-7178

Christian Andrighetto @ https://orcid.org/0000-0001-5184-9539

Maria Teresa Bottero (ํ) https://orcid.org/0000-0002-0803-9730

Alessandra Dalmasso (i) https://orcid.org/0000-0002-9991-9046 